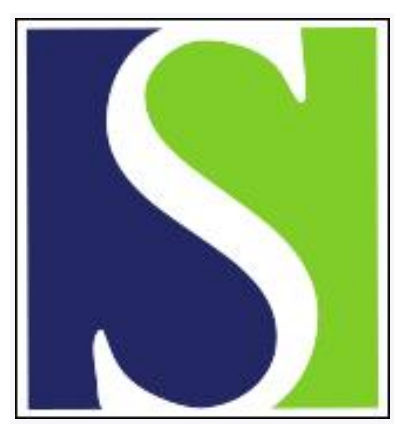

Scand J Work Environ Health 1983;9(2):219-222

https://doi.org/10.5271/sjweh.2421

Issue date: Apr 1983

Lungco measurement of particles retained in the lungs.

by Kalliomaki PL, Kalliomaki KK, Aittoniemi K, Korhonen OS

This article in PubMed: www.ncbi.nlm.nih.gov/pubmed/6648422

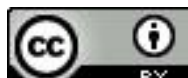




\title{
Lungco measurement of particles retained in the lungs
}

\author{
by Pirkko-Liisa Kalliomäki, MD, LSc (Eng), ${ }^{1}$ Kalevi K Kalliomäki, DSc (Eng), ${ }^{2}$ \\ Kari Aittoniemi, MSc (Eng), ${ }^{3}$ Olli S Korhonen, MD'
}

\begin{abstract}
KALLIOMÄKI P-L, KALLIOMÄKI KK, AITTONIEMI K, KORHONEN OS. Lungco measurement of particles retained in the lungs. Scand $j$ work environ health 9 (1983) 219-222. Nearly all metal dusts contain iron, which is one of the most common constituents in steel. Iron has one common ferrimagnetic oxide, magnetite. Although it is considered nontoxic, magnetite can be used as a tracer for more active and pathogenic constituents of inhaled dusts. After the chest area has been magnetized, magnetite produces a weak remanent magnetic field around the body. The field is measured and the amount of dust in the lungs is calculated on the assumption that the composition of lung dust is the same as that of airborne dust. This method has been applied to shipyard and stainless steel welders, to iron and steel workers, to stainless steel grinders, and to foundry workers. A clear magnetic signal was found for each subject. The maximum amount of lung dust found thus far was $10 \mathrm{~g}$ in the lungs of a stainless steel electrode welder. Referents showed signals of $0.5 \mathrm{mg}$ magnetite or less.
\end{abstract}

Key terms: biomagnetism, lung clearance, lung retention, magnetopneumography.

Nearly all metal dusts contain iron, which is the most common constituent in steel. Iron has one common ferrimagnetic oxide, magnetite. After the chest area has been magnetized, magnetite produces a weak remanent magnetic field around the body. The magnitude of this field is proportional to the amount of iron-containing dust in the lungs. The total amount of dust in the lungs can be calculated on the assumption that the composition of lung dust is the same as that of inhaled airborne dust. The iron serves as a tracer material for the measurement of more active and pathogenic constituents in inhaled dust. The iron itself is considered to be a harmless metal nontoxic to the lungs.

Small dust particles tend to be oxidized in the air. For this reason metallic iron is not usually found in airborne dust and fumes. In addition to oxides (magnetite and hematite), iron forms several com-

1 Institute of Occupational Health, Helsinki, Finland.

2 University of Oulu, Oulu, Finland.

3 Outokumpu Oy, Espoo, Finland.

Reprint requests to: $\mathrm{Dr}$ P-L Kalliomäki, Institute of Occupational Health, Haartmaninkatu 1, SF-00290 Helsinki 29, Finland. pounds with other elements in dusts. These compounds are usually neither ferromagnetic nor ferrimagnetic. The chemical analysis of dusts does not reveal their magnetic character.

Particles which contain magnetite remain magnetic after magnetization. There are two measures of this so-called remanent field, ie, the remanent magnetic moment, $\mathrm{m}_{\mathrm{r}}\left(\mathrm{Am}^{2}\right)$, or the specific remanent magnetic moment, $\mathrm{m}_{\mathrm{rs}}\left(\mathrm{Am}^{2} / \mathrm{kg}\right)$. The $\mathrm{m}_{\mathrm{rs}}$ of pure magnetite powder is about 7 $\mathrm{Am}^{2} / \mathrm{kg}$; the $\mathrm{m}_{\mathrm{rs}}$ of many metal dusts ranges between 0.1 and $1 \mathrm{Am}^{2} / \mathrm{kg}$ (17, 18, 19).

The specific remanent moment is proportional both to the product of the concentration of magnetite in the dust sample and to the coersive force of the dust (8). Because the coersive force depends on the process generating the dust and because it is independent of the mass or the concentration of magnetite in the sample, the coersive force can be used as a "fingerprint" of the dust. The coersive force varies between $3 \mathrm{kA} / \mathrm{m}$ and $30 \mathrm{kA} / \mathrm{m}(40$ oersted-400 oersted) in airborne dusts.

During the 10 years of its existence, the magnetic measuring technique has been 
used to study mild steel and stainless steel welders $(5,7,9,10,11,15)$, coal miners $(4,5,6)$, asbestos miners $(5,20)$, iron and steel workers $(1,17)$, and grinders and machinists $(5,18)$.

This method has been used in Finland since 1976. The original method presented by Cohen in 1973 and $1975(2,3)$ has been improved, and the magnetic properties of metal aerosols have been studied. Outokumpu Oy developed the prototype of an instrument called "Lungco," which has been tested in Finland and Sweden for the last two years. This review concentrates on introducing the method developed in Finland and its clinical applications.

\section{Method}

The equipment and the measuring procedure have been described in detail elsewhere (8). After the chest area has been magnetized in an external magnetic field, the magnetic field of the lungs is measured simultaneously on the anterior and the posterior sides with magnetometers. During the measurements the subject is moved back and forth (sweep) so that the remanent field can be mapped. The simultaneous measurement of the anterior and posterior sides allows higher disturbing fields than the measurement of one side because the system acts like a second-order gradiometer. The measuring time is about $10 \mathrm{~min}$. Most of this time is used to measure the "relaxation rate," ie, the slow disappearance of the remanent magnetic field due to the continuous motion of dust particles in living tissue (8). Since 1978 the magnetic moments measured have been corrected so that they correspond to circumstances $1 \mathrm{~min}$ after magnetization.

On the assumption that the composition of lung dust is known, the remanent magnetic moment can be converted to the total amount of dust in the area of the lungs. The properties of lung dust determine the error of the conversion. If the quality of the dust is known, the error is less than $10 \%$. But because of limited knowledge about the quality of the dust in the samples, the error is in most cases about $30 \%$. This is low enough for practical purposes, because the amount of dust in the lungs of workers from the same workplace varies greatly.

The lowest possible magnetic field which can be measured is about $10 \mathrm{pT}$. Thus the sensitivity of the measurement corresponds to about $0.5 \mathrm{mg}$ of magnetite. The repeatability of the measurement is $5 \%$. The resolution ability of the method is about the same as the measuring distance. It is always more than $10 \mathrm{~cm}$ however. The area of the lung can be divided in practice into eight areas (right/ left, anterior/posterior and upper/lower).

\section{Results and discussion}

Table 1 gives a short summary of the results obtained so far for different occupational groups with Lungco equipment.

Welders' exposure varies greatly depending on both environmental factors (such as the welding method and the material to be welded) and on individual factors (for instance, individual work habits and the rate of pulmonary ventilation - high during heavy work). There-

Table 1. Relaxation time and the amount of lung dust in different occupational groups measured by magnetopneumography.

\begin{tabular}{|c|c|c|c|c|c|}
\hline \multirow{2}{*}{ Group } & \multicolumn{2}{|c|}{$\begin{array}{l}\text { Exposure time } \\
\text { (years) }\end{array}$} & \multirow{2}{*}{$\begin{array}{c}\text { Relaxation } \\
\text { rate } \\
(\% / \mathrm{min})\end{array}$} & \multicolumn{2}{|c|}{ Lung dust (g) } \\
\hline & Mean & SD & & Mean & Range \\
\hline $\begin{array}{l}\text { Mild steel arc welders }(N=44) \\
\text { Stainless steel welders }\end{array}$ & 20 & 7 & 43 & 1.0 & $0.2-8.0$ \\
\hline $\begin{array}{l}\text { Tungsten inert gas }(N=21) \\
\text { Manual metal arc }(N=29) \\
\text { Workers in an iron factory }(N=27) \\
\text { Foundry workers }(N=10) \\
\text { Stainless steel grinders }(N=21)\end{array}$ & $\begin{array}{l}13 \\
19 \\
27 \\
33 \\
11\end{array}$ & $\begin{array}{r}9 \\
10 \\
5 \\
4 \\
4\end{array}$ & $\begin{array}{l}\overline{41} \\
59 \\
\overline{45}\end{array}$ & $\begin{array}{l}0.2 \\
4.0 \\
0.2 \\
0.2 \\
0.1\end{array}$ & $\begin{array}{l}0.0-0.5 \\
0.6-10 \\
0.02-1.0 \\
0.06-4.0 \\
0.02-1.8\end{array}$ \\
\hline
\end{tabular}


fore welders cannot be studied as one group, but as different groups within which there is great variation.

The exposure of shipyard welders is relatively homogeneous with regard to both the material to be welded (mild steel) and the welding method (manual metal arc). Despite the high interindividual scatter in the amount of lung dust, we found a significant difference between the results for workers from two different shipyards (10). Our results, which obviously indicate that different levels of pollutant are contained in the air of these shipyards, illustrate how measurements with Lungco could be used for the collection of information on which conditions can be improved. It is worth mentioning that even one month of working at a shipyard is sufficient to raise the amount of dust in the lungs to measurable levels (14).

The exposure conditions of individual workers for the past 10 to 20 years are not well known, but it is possible to estimate a typical exposure level. About $0.1 \%$ of the welding fumes inhaled during continuous, long-term exposure were retained in the lungs (9).

A preliminary approach to obtaining some understanding of the retention and clearance patterns of shipyard welders' lungs has been attempted (14). The average alveolar deposition rate varied from 50 to $130 \mathrm{mg}$ per year. The typical amount of alveolar retention after 10 years of continuous exposure was $1 \mathrm{~g}$. The clearance rate among retired welders ranged from 10 to $20 \%$ per year. After 10 years of exposure a leveling of lung retention was observed. However it is likely that the selection of workers modified the results, and the answers about the model of retention and clearance during lifetime exposure can be provided only by long-term follow-up studies.

A correlation was found between the radiological findings and the average magnetic field of shipyard welders $(10,11)$. It has been estimated that $400 \mathrm{mg}$ is the average minimum amount of dust which can cause radiographic findings (10). A good correlation was also found between the radiological findings and the magnetic mapping of contaminants in slices of the shipyard welders' lungs (16). The radio- logically positive opacities are thought to be caused by the increased endogenous accumulation of iron, which occurs as a reaction to exposure to manual metal arc (MMA) welding fumes from mild steel (10).

The retention fraction of inhaled particles among stainless steel MMA welders was about $1 \%$; among mild steel MMA welders the retention fraction was $0.1 \%$. Of all the industrial workers studied, stainless steel MMA workers had the highest retention fraction $(8,9,12)$. No typical micronodular changes were found in the chest radiographs of stainless steel MMA welders (11). There was a significant correlation between the average remanent magnetic fields of the stainless steel MMA welders' chests and the levels of chromium in their urine (15).

Neither the vital capacity nor the forced expiratory volume in $1 \mathrm{~s}$ correlated with the amount of dust in the lungs. On the other hand the maximal midexpiratory flow rate, the flow rates at the second half of the forced vital capacity, and the indices from nitrogen single breath tests were more often related to the amount of dust measured in the lungs (12).

Smokers generally have a somewhat lower amount of dust retained in their lungs than nonsmokers, but the difference is not usually statistically significant. The remanent filed decreases faster among smokers than among nonsmokers; this phenomenon indicates that the clearance mechanisms of smokers are altered.

The different stages of a typical iron and steel manufacturing process generate respirable dust which is $25-59 \%$ iron (17). The remanent magnetic moments of dusts and fumes originating from the different processes in an iron production plant vary from 1.2 to $2.6 \mathrm{Am}^{2} / \mathrm{kg}$ (8).

It has been reported that the approximate amount of contaminants in the lungs retained varied between 100 and $1,000 \mathrm{mg}$ for blast furnace workers and between $\mathbf{5 0}$ and $200 \mathrm{mg}$ for workers at a continuous casting process (17). These results agree well with the conditions of exposure estimated by the hygienic measurements of iron and steel factories.

Foundry workers are a rather heterogeneous group with respect to occupational exposure to dust. The concentrations of iron in the airborne dust present during 
different types of foundry work vary greatly. Therefore the magnetic properties of dust samples from different stages of the process also differ from each other. For an entire iron foundry, the average value of the remanent magnetic moment of dust samples was $0.5 \mathrm{Am}^{2} / \mathrm{kg}(8,13)$. According to a preliminary study clear remanent magnetic moments were measurable for subjects representing all of the typical foundry occupations. The estimated mean value of the retained dust was $200 \mathrm{mg}$ (13). Both "siderotic" and "silicotic" radiological changes in chest radiographs correlated with the amount of contaminants in the lungs (11).

\section{References}

1. Chiyotani K, Saito K, Kotani M, Uchikawa Y. Turukawa H. Measurement of lung's magnetic field in workers of steel-work. In: XX international congress of occupational health, Cairo 1981, p 538.

2. Cohen O. Ferromagnetic contamination in the lungs and other organs of the human body. Science 180 (1973) 745-748.

3. Cohen $O$. Measurements of the magnetic fields produced by the human heart, brain and lungs. IEEE trans magn 11 (1975) 694700 .

4. Dahn DC. Detection of ferromagnetic dust in the human lung. Dalhousie University, Halifax, Canada 1980, p 125.

5. Freedman AP, Robinson SE, Green HY Magnetopneumography as a tool for the study of dust retention in the lungs. Paper 4.4. Ann occup hyg 26 (1982) 320-337.

6. Freedman AP, Robinson $\mathrm{SE}$, Johnston RE. Non-invasive magnetopneumographic estimation of lung dust loads and distribution in bituminous coal workers. $J$ occup med 22 (1979) 613-618.

7. Freedman AP, Robinson SE, O'Leary $K$, Goodman L, Stellman LM. Non-invasive magnetopneumographic determination of lung dust loads in steel arc welders. $\mathrm{Br} j$ ind med 38 (1981) 384-388.

8. Kalliomäki $K$, Aittoniemi $K$, Kalliomäki P-L, Moilanen M. Measurement of lungretained contaminants in vivo among workers exposed to metal aerosols. Am ind hyg assoc j 42 (1981) 234-238.
9. Kalliomäki P-L, Aittoniemi $K$, Gustafsson $\mathrm{T}$, Kalliomäki K, Koponen M, Vaaranen V. Research on industrial ferrous metal aerosols. Ann occup hyg (1981) (in press).

10. Kalliomäki $P-L$, Alanko $K$, Korhonen $O$, Mattsson $\mathrm{T}$, Vaaranen $\mathrm{V}$, Koponen $\mathrm{M}$. Amount and distribution of welding fume lung contaminants among are welders. Scand $j$ work environ health 4 (1978) $122-130$.

11. Kalliomäki P-I, Huuskonen M, Korhonen $O$, Mattsson $T$, Sortti V, Vaaranen $V$, Kalliomäki $\mathbf{K}$, Koponen $\mathbf{M}$. Lung contamination of workers exposed to dust with an iron component. Arch hig rada toksikol 30 (1979): suppl, 893-902.

12. Kalliomäki P-L, Kalliomäki K, Korhonen O, Nordman $\mathbf{H}$, Rahkonen $\mathbf{E}$, Vaaranen $\mathrm{V}$. Respiratory status of stainless steel and mild steel welders. Scand $j$ work environ health 8 (1982): suppl 1, 117-121.

13. Kalliomäki P-L, Korhonen $\mathrm{O}$, Mattsson $\mathbf{T}$, Sortti V, Vaaranen V, Kalliomäki K, Koponen M. Lung contamination among foundry workers. Int arch occup environ health 43 (1979) 85-91.

14. Kalliomäki P-L, Korhonen $\mathrm{O}$, Vaaranen $\mathrm{V}$, Kalliomäki $\mathrm{K}$, Koponen $\mathbf{M}$. Lung retention and clearance of shipyard arc welders. Int arch occup environ health 42 (1978) 83-89.

15. Kalliomäki P-L, Rahkonen E, Vaaranen V, Kalliomäki $K$, Aittoniemi $K$. Lungretained contaminants, urinary chromium and nickel among stainless steel welders. Int arch occup environ health 49 (1981) $67-75$.

16. Kalliomäki P-L, Sutinen S, Kelhä V, Lakomaa E-L, Sortti V, Sutinen S. Amount and distribution of fume contaminants in the lungs of an are welder post mortem. $\mathrm{Br} \mathrm{j}$ ind med. 36 (1979) 224-230.

17. Koponen M, Gustafsson $T$, Kalliomäki $K$, Kalliomäki P-L, Moilanen $M$, Pyy $L$. Dusts in a steel-making plant. Int arch occup environ health 47 (1980) $35-45$.

18. Koponen M, Gustafsson $T$, Kalliomäki P-L, Kalliomäki $\mathrm{K}$, Moilanen M. Grinding dusts of alloyed steel and hard metal. Am occup hyg (in press)

19. Moilanen $\mathbf{M}$, Kalliomäki $\mathrm{K}$, Kalliomäki P-L, Aittoniemi $K$. Measurement of the magnetic properties of metal dusts and fumes. IEEE trans magn MAG-18/2 (1982) $788-791$.

20. Stroink G, Dahn D, Holland J. Magnetopneumographic estimation of lung dust loads and distribution in asbestos miners and millers. Am rev respir dis 123 (1981): $4,144-156$. 